Journal Home Page:

http://perlinguam.journals.ac.za

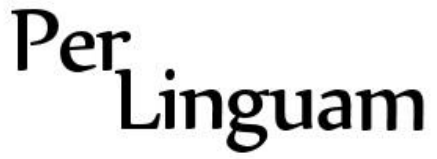

A Journal for Language Learning Tydskrif vir Taalaanleer

\title{
LINGUISTIC AND CULTURAL COGNITIVE RELEVANCE OF TELEVISED NARRATIVES TO THE NDEBELE CHILD IN BULAWAYO
}

\author{
Raphael Nhongo, Midlands State University, Zimbabwe
}

This paper focuses on narratives that are transmitted through South African Broadcasting Commission (SABC) television to the people of Zimbabwe, particularly children with Ndebele as their first language. Today, mainly in towns and cities, children no longer listen to folktales from grandmothers at home as the television has taken over that role. Because the Ndebele and Zulu languages are similar through being Nguni languages, most Ndebele people have resorted to SABC television as the Zimbabwe Broadcasting Corporation offers more programmes in Shona than in Ndebele. This paper traces the relevance of Zulu, which is the language used in the transmission and the Zulu culture which is contained within children's tales, particularly in YoTV Land, to the cognitive development of a child whose first language is Ndebele. Forty children were selected from two primary schools in Bulawayo as research participants to investigate how they are linguistically and culturally influenced by South African television. The paper ends by showing how narratives are influential in the cognitive development of a child and how the cognitive growth of a child who is exposed to two similar but different cultures and languages may be affected. The major effect is that those children who are below the age of nine years may not get the message being conveyed in the narrative since they have not been adequately exposed to linguistic and cultural variation and diversity.

Keywords: Narratives; folktales; cognitive development; language; culture; SABC television; Ndebele child

\section{INTRODUCTION}

The focus of this paper is on analysing how foreign media influences children's cognition particularly in the domains of language and culture. The paper traces the background of the adoption of foreign media in Zimbabwe, particularly in Bulawayo, and demonstrates how the social ordering and the socialisation of children have changed. Piaget's cognitive theory is used here to explore how South African Broadcasting Corporation (SABC) television influences language and cultural development and cognition among children in Bulawayo. The focus is on children who are between the ages of six and 13 years, who are of primary school age. It is also argued here that Zimbabwe's dominant language, which is Shona, also has an influence on children's understanding of Zulu folktales.

\section{SABC TELEVISION AND ITS POPULARITY IN BULAWAYO}

Studying the effects of the narrative tales on television is worthwhile as the television has become an agent of socialisation for children. The study focuses on folktales, since these attract the viewership of children on television. Language and culture are also of interest in this paper, since these variables are the most significant signs of cognitive growth that can be acquired 
through folktales. To justify this assertion, it is important to highlight that Tossa (2012: 195) mentions that she championed a storytelling project for children in 1992 in Thailand to revitalise the language and culture that had been lost through the adoption of western languages and culture, and the project yielded positive results. Haralambos and Holborn (2004), Tossa (2005), Akpinar and Ozturk (2009) and Marzolph (2012) have observed that storytelling is important in teaching and preserving language and culture. Samaniego and Pascual (2007) point out that the quest for knowing the limits and advantages of television may be a first step towards studying television narratives from a critical standpoint. This paper studies how viewing SABC television of a neighbouring country (South Africa) influences the linguistic and cultural cognitive development of children in Bulawayo, Zimbabwe. SABC television has gained popularity in Zimbabwe, particularly in Bulawayo; thus, it is important to first trace why the people of Bulawayo have gained so much interest on SABC television and have abandoned their own local Zimbabwe Broadcasting Corporation (ZBC) television.

The popularity of the SABC in Bulawayo is rooted in a variety of historical encounters that fall under political, social, cultural and sociolinguistic factors. The Ndebele language, together with Zulu, Xhosa, Swati and South African Ndebele, is a Nguni dialect. Zulu, Xhosa, Swati and South African Ndebele are all spoken in South Africa, while only Zimbabwean Ndebele is spoken outside the borders of South Africa. The Ndebele people are the descendants of the Zulu who fled away from king of the Zulu Tshaka with their king Mzilikazi in the first quarter of the $19^{\text {th }}$ century. The Ndebele language today still resembles the Zulu language. In terms of dominance in Zimbabwe, the Ndebele follow after the Shona group, who are dominant in terms of numbers, political representation, geographical space and language. At the inception of colonialism, the Ndebele with their king Lobengula were the dominant group, but soon after the attainment of independence in 1980, the Shona became an unquestionably dominant group in politics, power and language. Hachipola (1998: xxi) points out that 'Shona has a much higher status than Ndebele. In the media, for example on television and radio, news is read in Shona first.' Ndhlovu (2006: 305) also notes that 'The Ndebele language has always been systematically marginalised in education, in the media, in the judicial system, in business and commerce as well as in general public life.' Feeling that their language is being marginalised made the Ndebele people opt for $\mathrm{SABC}$ television, because the fact that some of the languages that are used on SABC television are mutually intelligible with Ndebele means that they can understand the language that is used in broadcasting.

In 2001, the Zimbabwean government, through the Ministry of Information and Publicity, introduced $75 \%$ local content on ZBC, which entailed that $75 \%$ of programmes to be aired on both television and radio were supposed to be locally produced. Mda (2010: 85) points out that people around the world have expressed an increasing desire to protect their national identity, values and beliefs through a range of policies, such as the introduction of the local content in the media. Moyo (2004: 12) argues that broadcasting in Zimbabwe has always been a contested terrain since its introduction in the 1930s in the then Rhodesia. He further notes that, in both preand post-independence governments, the ruling elite has used broadcasting as a tool for political control and manipulation of the masses (Moyo, 2004: 12). The Ministry of Information and Publicity encouraged the Zimbabweans to produce local films and music, but the products that surfaced in abundance were in the Shona language, which meant continued dominance of the 
Shona language on television. The Ndebele people felt marginalised in the media and thus they opted for South African television through the use of satellite receivers. According to Mda (2010: 84) and Rohn (2010: 18), local content is common in the world over, especially in America, Europe and Asia, but it is mainly there to promote the local products, the local languages and the local cultures of those nations. Singham (2007: 435) notes that, despite considerable state ownership of media channels and the implementation of local content, many developing countries have not produced many programmes for broadcasting through their channels. The abundance of Shona programmes on national television resulted in the people of Bulawayo shunning ZBC television and opting for SABC television via satellite where they felt a sense of belonging since they feel more comfortable watching programmes that are broadcast in Zulu than those broadcast in Shona.

The free-to-air satellite receivers such as Wiztech, Philibao, Fortech Star, Supertech and Vivid saw almost all households in Bulawayo shunning ZBC television and opting for SABC from 2007 to date. However, SABC television disconnected its services to the free-to-air channels in July 2013 but most people found it better to opt for Digital Satelite Television (DStv) so that they could continue accessing SABC television rather than turning back to ZBC. A number of researchers, particularly Moran and Keane (2004), Vijayalashmi (2005), Keane, Fung and Moran (2007), and Bielby and Harrington (2008), have discovered that viewers will always opt for television channels that offer high quality programmes regardless of the fact that such channels are foreign or local. Mda (2010: 90) highlights that South Africa came up with a broadcasting policy in 1999 with the aim of fostering local content which had two goals, social and economic in nature, aimed at empowering South African nationals and redressing the imbalances that were created by the apartheid system. Policies that are put in place to control a people who are already protesting against their government are not usually welcomed by the masses and thus the $75 \%$ local content in Zimbabwe was not welcomed because that policy came at a time when the people of Zimbabwe were beginning to feel the economic hardships which they felt were as a result of their government. They were also convinced that this $75 \%$ local content was more political than a policy meant to promote local artists.

The period soon after independence, between 1982 and 1987, was characterised by clashes between the Shona and the Ndebele people, resulting in the death of many people in Matabeleland as the Shona people aligned themselves to ZANLA and the Ndebele to ZIPRA which were the liberation movements during the struggle for independence (Cornwell \& Stoddard, 2001; Muzondiya, 2009; Msindo, 2012). The people of Matabeleland and the Midlands, particularly the Ndebele, fell victim to the violence that was taking place. Most of the Ndebele people skipped the border and went to South Africa where they worked while they were hiding. Upon their return, they were called the Injiva and had accumulated some wealth. Those clashes made the Ndebele people to have an aversion of the Shona and even today the reason why they shun Shona programmes that are broadcast on ZBC television hinges on memories that they have about the brutality that was unleashed on them.

The search for greener pastures also resulted in most Zimbabweans, especially from Matabeleland, migrating to South Africa. Migration for the search of employment dates back to the colonial period when a number of men moved to South Africa in large numbers through an agency called the Witwatersrand Native Labour Association (WNLA, now known as WENELA) Per Linguam 2017 33(2):51-62 http://dx.doi.org/10.5785/33-2-683 
to work in the mines (Nyandoro, 2011: 114). The introduction of the Economic Structural Adjustment Programme (ESAP) in 1991, which saw the economic collapse reflected through massive retrenchments, joblessness and exorbitant hikes in basic services, accelerated migration to South Africa (Nyandoro, 2011: 114). Many people were forced by the severe economic hardships that were felt mainly between 2000 and 2009 to cross the borders to South Africa (McGregor, 2010: 3). Those who came back home were respected for their financial standing in society since they could afford a great deal of services and commodities that many people who worked locally could not afford. People in Bulawayo started to associate themselves with South Africa more than they did with Zimbabwe and thus also bought and installed some satellite receivers. Although Ndebele has slightly diverged from Zulu (Hadebe, 2002), most people in Bulawayo have fallen back to Zulu, because to them Zulu is a language that is associated with social and economic prestige. In 2009, a multicurrency economy was introduced and as such, most people's lives improved and saw a satellite dish being installed on almost every house in Bulawayo. This led to the people of Bulawayo becoming acquainted to the current affairs of South Africa more than they did with those of Zimbabwe.

\section{TELEVISION AND CHILD SOCIALISATION}

Socialisation is a process by which children learn the rules and regulations of their own family group, their culture, and their society. Socialisation refers to the learning of information, cognitive processes, values, attitudes, social roles, self-concepts, and behaviours that are generally accepted or expected (Berry, 1998: 233). To Haralambos and Holborn (2004), socialisation is the process by which individuals learn the culture of their society. In African societies, children used to be socialised by members of the extended family, particularly grandmothers, when it came to socialisation through folktales. Today, the television has taken over the role of grandmothers due to urbanisation, which favours the nuclear family as opposed to the traditional extended family. 'The messages and images of television consciously and unconsciously compete with and challenge the teachings in the home and other institutions concerned with the growth and development of young people' (Berry, 1998: 234). This means that, although the television has always been regarded as a secondary agent of socialisation, it is also part of the nuclear family's very operation. The television seems to be even more attractive than the family and children in urban areas spend most of their time on it. According to Berry (1998: 234), television is not only entertainment for children; it is an important socialiser and an important source of vicarious learning to them. Children are not only entertained by the television, but also acquire language and culture from it. This becomes problematic when children spend all their television viewing time watching television that broadcasts in a language that has some differences from theirs. In the case of the Ndebele children in Bulawayo, whose language is mutually intelligible with Zulu, although there are many variations, they are bound to face some linguistic cognitive development challenges if the television is to be regarded as a source of language acquisition and learning.

\section{METHODS, THEORETICAL FOUNDATION AND SCOPE}

Forty children from two different primary schools of ages between six and 13 years were used as research participants in this study. These two primary schools are in Bulawayo and 20 children were drawn from each of these schools. The children were asked to write those folktales that

Per Linguam 2017 33(2):51-62

http://dx.doi.org/10.5785/33-2-683 
they have seen and heard being narrated on SABC television so as to check on their understanding of those folktales. They were also asked to narrate what they learnt from these folktales so as to understand if these children were benefitting cognitively from those tales. Twenty terms, which included those that differ semantically from Ndebele, homonyms, those that children are unfamiliar with, those similar in form to the Ndebele ones, and those that are similar to Shona terms that are popularly used on SABC morning programmes for children, particularly in YoTV Land and Takalani Sesami where Gundi no Mazwi also feature, were selected and these were given to the children for them to provide Ndebele equivalents. This was meant to investigate whether the children got the meaning conveyed in the Nguni languages used on SABC television. The researcher first sought clearance from the Ministry of Primary and Secondary Education to conduct research in schools. As another way of adhering to research ethics, the researcher did not have direct contact with the school children but the class teachers, whom the children were used to, conducted data collection on behalf of the researcher.

This paper was guided by cognitive theory because the study was mainly concerned with the processes that take place in the minds of children with regard to culture and language as they watch and listen to folktales on SABC television. The cognitive theory was propounded by the likes of Piaget, Vygotsky, Eisenburg and Bruner in the 1950s and was further explained in a linguistic dimension by Noam Chomsky in 1957 (Lefrancois, 2012: 206). Emphasis of the cognitive approach is on linguistics, memory, and developmental psychology. According to Matlin (2003: 2), 'Cognition, or mental activity, describes the acquisition, storage, transformation, and use of knowledge.' This explains that human beings acquire knowledge through experience and observation (Matlin, 2003). Cognitive theory is concerned with the development of a person's thought processes.

According to Piaget (1983), children develop through a series of four key stages, which are the sensorimoter stage, from birth to age two; the preoperational stage, from age two to about age seven; the concrete operational stage, from age seven to 11; and the formal operational stage, which begins in adolescence and spans into adulthood. However, since the paper is mainly focusing on children who are between the ages of six and 13 years, the age group that is found in primary school in Zimbabwe, concrete operational stage is therefore adopted for analysis here. The concrete operational stage is the stage of cognitive development in which children begin to use logical instead of intuitive, perception-bound reasoning (Swartwood \& Trotter, 2004). According to Piaget, in the concrete operational stage, children begin to think more logically, but their thinking can also be very rigid. They tend to struggle with abstract and hypothetical concepts (Cherry, 2013). Piaget considered the concrete stage a major turning point of the child's cognitive development, because it marks the beginning of logical or operational thought (McLeod, 2010). Children's thinking style gradually becomes more logical, organised, and flexible as they enter Piaget's concrete operational stage. The child at this stage can apply logic to physical objects and thus it is called concrete operational (McLeod, 2010; and Swartwood \& Trotter, 2013).

Another idea that is used as a point of departure in this paper is that concrete operational children recognise that people see things in different ways because of different situations and different sets of values (Rathus, 2011). This idea is used in this article to check whether children who watch and listen to folktales on SABC television are aware that the same concept or message can Per Linguam 2017 33(2):51-62 http://dx.doi.org/10.5785/33-2-683 
be conveyed in different ways and in a different language from their first language. This idea is also used to assess the extent to which the Ndebele children were cognisant of what was conveyed in folktales in Zulu language on SABC television.

\section{NARRATIVES ON SABC TELEVISION}

The most popular platform on SABC television with children in Bulawayo is YoTV Land on SABC1, which features their favourite cartoon folktale film called UGundi no Mazwi. YoTV runs throughout the week from Monday to Sunday. From Monday to Friday, YoTV is screened from 06:30 to 07:30. On Saturdays, the programme runs from 07:30 to 08:30, while on Sundays it runs from 07:30 to 09:00. On Wednesdays, there is a special edition which features Mvubu and Friends, a cartoon film of animals where the main character is a hippopotamus. On Sundays, there is also a special edition that is mainly devoted to the screening of fairy tales.

Narratives are an important source of a society's history, morals and values. Samaniego and Pascual (2007: 7) point out that narrative tales provide values and specific identity elements. They go further to note that the historical narratives convey an image of society and its moral features (Samaniego \& Pascual, 2007: 8). However, it is questionable whether those narrative tales that are broadcast on SABC television convey morals and values of a Ndebele child in Bulawayo in the truest sense, since they are designed to convey Zulu morals and values.

Theodosiadou and Markos (2013: 36) have observed that a considerable body of research argues that television viewing has both a positive and a negative impact on children's learning. It is incontestable that children learn from the folktales that are broadcast on SABC television, although the Ndebele children might find it difficult to comprehend the Zulu language that is used. However, as has been pointed out, children learn a great deal from television since they now spend most of their time viewing television when they are not at school. Although television has some negative impacts, the positive effects far outweigh the negative ones, especially when considering the broadcasting policies that a number of countries have adopted. SABC television always highlights if the programme being broadcast or about to be broadcast may have any negative effects on children by putting age specifications or indicating whether the programme contains strong language and/or violence.

\section{IMPLICATIONS OF MUTUALLY INTELLIGIBLE LANGUAGES ON THE COGNITIVE DEVELOPMENT OF CHILDREN}

Zulu and Ndebele are perceptibly mutually intelligible, but most of the terms in these two languages actually prove to be different in both structure and meaning. It was realised that children do not understand the meanings of some of the Zulu terms that are used in the narration of folktales on SABC television due to a number of factors that are outlined in the following paragraphs. In this section, only a sample of terms are used to illustrate some of the findings. It came out clearly that children in Bulawayo do not understand some of the Zulu terms that are used in narrating folktales on SABC television, particularly homonyms. Homonyms are words or lexemes which have the same form, but differ in meaning (Lyons, 1977: 22). De Groot (2011: 166) notes that interlexical homonyms pose a challenge among children when it comes to cognition. In a set of 35 lexemes given to pupils so that they could provide meanings, eight were 
homonyms. A list of homonyms that were given to pupils, together with the meanings that the children gave, is presented in Table 1 below.

Table 1: The children's understanding of homonyms shared by the Ndebele and Zulu languages, with Zulu as the host language

\begin{tabular}{|c|c|c|c|c|c|c|}
\hline \multirow{2}{*}{$\begin{array}{c}\text { Homonym } \\
\text { (Zulu) }\end{array}$} & \multirow[b]{2}{*}{ Zulu meaning } & \multirow[b]{2}{*}{$\begin{array}{l}\text { Ndebele } \\
\text { meaning }\end{array}$} & \multicolumn{3}{|c|}{ Answers given by pupils and statistics } & \multirow[b]{2}{*}{$\begin{array}{c}\text { Number } \\
\text { of } \\
\text { correct } \\
\text { answers } \\
\text { in Zulu }\end{array}$} \\
\hline & & & $1^{\text {st }} t$ answer & $2^{\text {nd }}$ answer & $\begin{array}{c}3^{\text {rd }} \\
\text { answer }\end{array}$ & \\
\hline ukuphuza & To drink & $\begin{array}{l}\text { To be late for } \\
\text { something }\end{array}$ & $\begin{array}{l}\text { ukuphuza (to be } \\
\text { late for } \\
\text { something) } \\
14\end{array}$ & $\begin{array}{l}\text { ukuselwa (to } \\
\text { be late for } \\
\text { something) } \\
9\end{array}$ & & 17 \\
\hline ukukhokha & To pay & $\begin{array}{l}\text { Preparing to } \\
\text { take a rest }\end{array}$ & $\begin{array}{l}\text { ukuphumula (to } \\
\text { rest) } \\
9\end{array}$ & $\begin{array}{l}\text { ukuphefumula } \\
\text { (to breathe) } \\
16\end{array}$ & $\begin{array}{l}\text { ukubizal } \\
\text { ukunxusa } \\
\text { (to } \\
\text { invite) } \\
11\end{array}$ & 4 \\
\hline isondo & A tyre or wheel & A hoof & $\begin{array}{l}\text { impondo (horns) } \\
2\end{array}$ & $\begin{array}{l}\text { insonto } \\
\text { (church) } \\
16\end{array}$ & $\begin{array}{l}\text { Don't } \\
\text { know } \\
22 \\
\end{array}$ & 0 \\
\hline indwangu & A piece of cloth & A baboon & $\begin{array}{l}\text { indwangu } \\
\text { (baboon) } \\
18\end{array}$ & $\begin{array}{l}\text { Don’t know } \\
2\end{array}$ & & 20 \\
\hline amazambane & Potatoes & Groundnuts & $\begin{array}{l}\text { amazambane } \\
\text { (groundnuts) } \\
19\end{array}$ & & & 21 \\
\hline phuza & Drink & $\begin{array}{l}\text { Be late for } \\
\text { something }\end{array}$ & $\begin{array}{l}\text { phuza (be late for } \\
\text { something) } \\
11\end{array}$ & $\begin{array}{l}\text { selwa (be late } \\
\text { for something) } \\
10\end{array}$ & & 29 \\
\hline umuthi & A tree & Medicine & $\begin{array}{l}\text { umuthi (medicine) } \\
31\end{array}$ & $\begin{array}{l}\text { Don’t know } \\
9\end{array}$ & & 0 \\
\hline ebizayo & $\begin{array}{l}\text { An expensive } \\
\text { one }\end{array}$ & $\begin{array}{l}\text { One that is } \\
\text { calling }\end{array}$ & $\begin{array}{l}\text { obizayo (one who } \\
\text { is calling) } \\
17\end{array}$ & $\begin{array}{l}\text { Don't know } \\
15\end{array}$ & & 8 \\
\hline
\end{tabular}

A number of factors resulted in the children not being aware of what was being conveyed through some words that are shared by Zulu and Ndebele but carry different meanings. Some of the meanings that were given by children as responses demonstrated some influence of the Shona language on children's understanding of Zulu. For the Zulu word isondo (wheel or tyre), the meaning that was given is insonto (church), for which the Shona equivalent is sondo. For the Zulu word ukukhokha (to pay), the meaning that was given is ukubiza/ukunxusa (to invite), which in Shona is represented by the word kukoka. It also has to be brought to the attention of the reader that some first-language speakers of Ndebele in Bulawayo may have one Shona parent, resulting in the child becoming bilingual. In most instances, parents are first-language speakers of Shona and when children are at home they use Shona, whereas at school or when 
talking to friends they use Ndebele, which is the most dominant and official indigenous language in schools in Bulawayo.

Another reason why children do not comprehend what is conveyed through Zulu language in folktales that are broadcast on SABC television is their unfamiliarity with Zulu. Words such as amantongomane (groundnuts), isigcoko (hat), imvula (rain), ukweba (to still) and imfene (baboon) are not known by the children as they do not use them from day to day but only hear them in the narration of folktales on SABC television. Such words pose a challenge on the children's cognition with regard to the message being conveyed. Ultimately, children who listen to these folktales end up getting an inaccurate understanding of the messages being conveyed. The children were unfamiliar with these words because they lacked knowledge of Zulu culture and language. The meanings of words that children were unfamiliar with were understood as indicated in Table 2.

Table 2: Children's understanding of the terms that were unfamiliar to them

\begin{tabular}{|l|l|l|}
\hline Unfamiliar word & Proper meaning & Perceived meaning \\
\hline amantongomane & groundnuts & amantombazane (girls) \\
\hline isigcoko & hat & isigqoko (dress) \\
\hline imvula & rain & amanzi (water) \\
\hline ukweba & to still & ukuloya (bewitching) \\
\hline imfene & baboon & imfe (sweet reeds) \\
\hline
\end{tabular}

The most interesting case here is again the influence of the Shona language. The Zulu word imvula is similar to the Shona word mvura, which means 'water' or 'rain' in the Shona language and because these children were familiar with Shona, they therefore perceived it from a Shona perspective and gave its Ndebele equivalent as amanzi (water). The children also demonstrated that they were unfamiliar with some Zulu words such as ibhubesi (a lion), ikati (a cat), shesha (be quick/fast), and ekugcineni (at the end). Pupils could not give accurate explanations of what these words signify, which shows that, although these words were used in the media that the children were acquainted with, they were still not familiar with what the words mean. Some other Zulu words were perceived according to their similarity in form and sound with other Ndebele words. The word amantongomane is similar in form and sound to amantombazane, isigcoko is similar to isigqoko and imfene is similar to imfe. This proves that children use form and sound similarity as a strategy for cognition when they meet expressions with which they are unfamiliar. Aukrust (2011: 187) is of the opinion that children recognise most of the unfamiliar words by looking at them and applying a variety of strategies to comprehend them. However, in folktales on television where words are largely presented in audio mode, it becomes even more difficult for children to understand some of these unfamiliar words because they do not always have a chance to view their form but only pick sounds during the narration.

\section{DIVERSE CULTURES ON TELEVISION AND COGNITIVE GROWTH}

Children also learn about their culture from the television. Through television, according to Kapoor (2003: 2): 
The child develops abilities to go beyond the perceptual appearances, acquire information-processing skills to organize and use what he learns about his environment and develops a deeper understanding of interpersonal situations, which allow him to see the world through multiple perspectives during his stages of cognitive development.

This is a clear indication that children also acquire language and culture through television, since it is the most immediate agent of their socialisation in urban areas. The dilemma lies in how that language and culture will help them to grow cognitively within the canons of the society in which they live. It was realised that the Ndebele children in Bulawayo are exposed to two major institutions of socialisation, namely, the school and the home. At home, children are socialised by their parents, peers and siblings, as well as through media, particularly the television. At school, socialisation is done by teachers, through playing and talking to their peers and through other extracurricular activities such as clubs and sports. O'Dell (1978: 49) observes that:

In a pluralistic society, the demands made on a child are both fewer in number and more various. One set of values is taught to him in school another at home, another on television, another at scout meetings, another in comics, and these different sets of values are often, at least in part contradictory. The situation is often even more complex-for all is not unified even within a given agency of socialization.

Some of the concepts that are contained in some of the folktales on SABC television are not part of the Ndebele culture and, as a result, socialisation of Ndebele children through SABC television is compromised. Schaefer (2006: 98) puts it clearly that, although the media is good as an agent for socialisation of children, there are other problems inherent in the socialisation function of television. However, exposing children to two different cultures and languages helps to facilitate effective cognitive development, since they are made to understand issues from different languages and cultural contexts.

It also became clear that those children who were below the age of nine years could not notice the difference between cultures and languages. They did not notice that the SABC was broadcasting in a foreign language or that the culture being conveyed on SABC television was a foreign culture. However, those who were nine years and above could notice that Zulu was a foreign language and that some concepts were carried were different from those of the Ndebele culture. Akpinar and Ozturk (2009) are of the view that folktales are a useful tool for increasing the understanding of a foreign language and multicultural awareness. Theodosiadou and Markos (2013: 36) point out that it has been widely recognised that television viewing has primarily negative effects on very young school-going children as far as cognitive and behavioural development is concerned. From the study, it was realised that only those children who are advanced in terms of age are aware of linguistic and cultural diversity, especially where mutual intelligibility exists. It became apparent that those below the age of nine have not reached the stage where they are aware of linguistic and cultural diversity.

What was also noticed about folktales that are narrated on SABC television is that some of them are common in the Ndebele culture, what differs is just some of the terms that are used in Zulu and Ndebele languages. Most African societies share similar folktales, and that is the case with Ndebele and Zulu societies. Akpinar and Ozturk (2009: 71) observe that folktales are an 
excellent way of introducing children to other societies and, because folktales mirror a society's culture, children are exposed to a culture's unique beliefs, values, lifestyles and history. Through multicultural folktales, children can see that people from different societies share similar emotions and needs. Folktales make mature children understand what is happening in other societies and they are afforded the opportunity to compare their own societies with others. It was also realised that, with common folktales across cultures, children watching and listening to these folktales can learn the language in which these folktales are being broadcast, especially where the two languages are mutually intelligible. The Ndebele children watching and listening to folktales being narrated in Zulu on television would be in a position to learn some of the Zulu terms that do not exist in the Ndebele language because of familiarity with the folktale complemented with visual aids.

\section{CONCLUSIONS AND RECOMMENDATIONS}

The popularity of SABC television in Bulawayo strongly relates to the historical experiences of the Ndebele people which include the dominance of Shona over the Ndebele language; the quality of programmes; mutual intelligibility between Zulu and Ndebele; the introduction of freeto-air channels which were a sign of prestige and economic standing in society; migration to South Africa in search for greener pastures; and the tribal clashes between the Shona and the Ndebele that took place between 1982 and 1987. It was realised that the dominance of Shona, migration and intermarriages between the Shona and the Ndebele in Zimbabwe also influence children's cognition when it comes to words that are homonyms that exist in both Zulu and Ndebele. It was also noticed that, although it has traditionally been believed that television viewing has negative effects on children, the positive effects far outweigh the negative ones. It was also realised that the television plays a significant role in the socialisation of children since they spend most of their time viewing television when they are not at school. The most interesting observation that was made was that young children who are below the age of nine years face some challenges when it comes to cognition, especially when they are introduced to an unfamiliar language and culture. Those who are aged nine years and above notice linguistic and cultural diversity when they are viewing foreign television, especially where the cultures and languages are similar, as in the case of Ndebele and Zulu. It was also noticed that viewing of television that is broadcast in a language that carries some differences from that of the children who are below the age of nine years makes it difficult for them to understand the message being conveyed and does not fully contribute to their linguistic development.

It is important for local television broadcasters to evaluate their programmes by seeking viewers' opinions. All national languages should have equal representation in the programmes that are aired on national television. This can also be achieved through going back to the consumers to seek their opinions on what they feel about their linguistic representation on national television and the quality of programmes. The local broadcaster should always be cautious of foreign television channels that are a threat to local media and try to broadcast those programmes that capture the interests of the viewers. However, in trying to compete with foreign media broadcasters, the local broadcaster should air programmes that are culturally and linguistically relevant to its viewers. The cognitive development of children should be considered when it comes to programmes that are specifically for children.

Per Linguam 2017 33(2):51-62

http://dx.doi.org/10.5785/33-2-683 


\section{REFERENCES}

AKPINAR, KD \& MS OZTURK. 2009. Teaching culture and language through folktales. Ekev Academic Review, 13(40):69-84.

AUKRUST, VG (Ed). 2011. Learning and cognition in education. Oxford: Academic Press.

BERRY, GL. 1998. Black family life on television and the socialization of the African American child: images of marginality. Journal of Comparative Family Studies, 29(2):233-242.

BIELBY, DD \& CL HARRINGTON. 2008. Global TV: exporting television and culture in the world market. New York: New York University Press.

CORNWELL, GH \& EW STODDARD (Eds). 2001. Global multiculturalisim: comparative perspectives on ethnicity, race, and nation. Maryland: Rowman and Littlefield.

DE GROOT, AMB. 2011. Language and cognition in bilinguals and multilinguals: an introduction. New York: Psychology Press.

HACHIPOLA, SJ. 1998. A survey of minority languages in Zimbabwe. Harare: University of Zimbabwe Publications.

HADEBE, S. 2002. The standardisation of the Ndebele language through dictionary-making. ALRI: University of Zimbabwe.

HARALAMBOS, M \& M Holborn. 2004. Sociology: themes and perspectives. London: Harper Collins.

KAPPOR, N. 2003. Television, advertising and consumer response. New Delhi: Mittal Publications.

KEANE, M, AFY FUNG \& A MORAN. 2007. New television, globalisation and the East Asian cultural imagination. Hong Kong: Hong Kong University Press.

LEFRANCOIS, GR. 2012. Theories of human learning: what the professor said. Belmont: Wadsworth.

LYONS, J. 1977. Semantics. Cambridge: Cambridge University Press.

MARZOLPH, U. 2012. Cultural property and the right of interpretation: negotiating folklore in the Islamic Republic of Iran. Journal of Folklore Research, 49(1):1-24.

MATLIN, MW. 2003. Cognition. Hoboken, NJ: Wiley.

McGREGOR, J. 2010. Introduction: the making of Zimbabwe's new diaspora. In McGregor, J \& R Primorac (Eds), Zimbabwe's new diaspora: displacement and the cultural politics of survival. New York: Beghahn. 1-36.

MDA, M. 2010. Localism in the South African media context: a comparison of the South African local content and Canadian content rules. In Nwokeafor, CU \& K Langmia (Eds), Media and technology in emerging African democracies. Maryland: University Press of America. 83-104.

MORAN, A \& M KEANE (Eds). 2004 Television across Asia: television industries, programme formats and globalisation. London: Routledge Curzon.

MOYO, D. 2004. From Rhodesia to Zimbabwe: change without change? Broadcasting policy reform and political control. In Melber, $\mathrm{H}$ (Ed), Media, public discourse and political contestation in Zimbabwe. Uppsala: Nordiska Afrikainstitutet. 12-28.

MSINDO, I. 2012. Ethnicity in Zimbabwe: transformations in Kalanga and Ndebele societies, 1860-1900. Rochester: University of Rochester Press.

Per Linguam 2017 33(2):51-62

http://dx.doi.org/10.5785/33-2-683 
MUZONDIYA, J. 2009. From buoyancy to crisis, 1980-1997. In Raftopulos, B \& A Mlambo (Eds), Becoming Zimbabwe: a history from the pre-colonial period to 2008. Harare: Weaver Press. 167-200.

NDHLOVU, F. 2006. Gramsci, Doke and the marginalization of the Ndebele language in Zimbabwe. Journal of Multilingual and Multicultural Development, 27(4):305-318.

NYANDORO, M. 2011. The influx of Zimbabwean migrants into South Africa. In Guild, E \& S Mantu (Eds), Constructing and imagining labour migration: perspectives of control from five continents. Surrey: Ashgate Publishing Limited. 109-136.

O'DELL, FA. 1978. Socialisation through children's literature: the Soviet example. Cambridge: Cambridge University Press.

PIAGET, J. 1983. Piaget's theory. In P Mussen (Ed), Handbook of child psychology. New York: Wiley.

RATHUS, SA. 2011. Childhood and adolescence: voyages in development. Belmont: Wadsworth.

ROHN, U. 2010. Cultural barriers to the success of foreign media content: Western media in China, India and Japan. Frankfurt: Peter Lang.

SAMANIEGO, CM \& AC Pascual. 2007. The teaching and learning of values through television. Review of Education, 53:5-21.

SCHAEFER, RT. 2006. Sociology: a brief introduction. New York: McGraw-Hill.

SINGHAM, S. 2007. A general theory of trade liberalisation and competitive markets. London: Cameron May.

SWARTWOOD, MO \& KH TROTTER. 2004. Observing children and adolescents: student workbook. Belmont: Wadsworth.

THEODOSIADOU, S \& A MARKOS. 2013. Attitudes of preschool teachers in northern Greece on children and TV viewing. Australasian Journal of Early Childhood, 38(3):36-44.

TOSSA, W. 2005. Story telling: a means to revitalize a disappearing language and culture in northeast Thailand (Isan). Knowledge Quest, 36(5):50-56.

VIJAYALASHMI, P. 2005. Foreign television and Indian youth: changing attitudes. New Delhi: Ashkor Kummar Mittal.

WA THIONG'O, N. 1981. Decolonising the mind: the politics of language in African literature. Harare: Zimbabwe Publishing House.

\section{BIOGRAPHICAL NOTE}

Raphael Nhongo is a lecturer in the Department of African Languages and Culture at the University of Zimbabwe.

Email nhongor@msu.ac.zW

Per Linguam 2017 33(2):51-62

http://dx.doi.org/10.5785/33-2-683 